\title{
Presidents, Policy Compromise, and Legislative Success
}

\author{
Christian Arnold, University of Mannheim \\ David Doyle, University of Oxford \\ Nina Wiesehomeier, IE School of International Relations
}

\begin{abstract}
Presidents play a central role in legislative activity in Latin America. Previous research highlights that some form of ideological compromise on behalf of the president is vital to sustain successful legislative coalitions. Yet, primarily due to the lack of a firm empirical basis on which to measure such presidential give-and-take, the extent to which presidents make use of such policy compromise, and under what conditions this is a viable strategy, remains unknown. Applying quantitative text analysis to 305 annual "state of the union" addresses of 73 presidents in 13 Latin American countries, we remedy this situation and provide comparable time-series data for Latin American presidential movements in a onedimensional issue space between 1980 and 2014. Our results indicate that presidents will compromise in response to changes in the median party, although this effect will be mediated by the institutional context within which the president operates.
\end{abstract}

ust over three decades ago Linz (1990) warned of the dangers of presidentialism. For Linz and others (e.g., Stepan and Skach 1993), the apparent fragility of presidential democracies relative to parliamentary systems is rooted in the psychological incentives that stem from the direct election and fixed term of the presidential office, which are thought to foster an imperial and intolerant governing style among presidents and to remove the incentive for compromise and coalition building. This will cultivate conflict between the executive and legislative branches, particularly in minority government situations, resulting in legislative deadlock and, eventually, democratic breakdown (Maeda 2010; Mainwaring 1993).

The past 30 years have demonstrated, however, that legislative deadlock between both branches of government in presidential systems is far from the norm, inspiring extensive revisionist interpretations of executive-legislative relations in separation of power systems. For example, recent work suggests that coalitions are a regular feature of multiparty presidential systems (Cheibub et al. 2004) and a common means to secure successful legislative outcomes (Alemán and Tsebelis 2005; Amorim Neto 2006; Chasquetti 2001; Negretto 2006) as presidents will bargain - both through material resources and through informal channels - to ensure that policy is passed (Abranches 1988; Cox and Morgenstern 2001; Figueiredo and Limongi 2000; Mejía Acosta 2009). An implicit assumption in much of this work is that some form of ideological compromise on behalf of the president is an integral part of the legislative process (Amorim Neto 2002; Colomer and Negretto 2005; Cox and Morgenstern 2001; Raile, Pereira, and Power 2010). Indeed, for Cox and Morgenstern (2001, 171), the actions of the president are conditioned by the threat of legislative veto, and so at times "they make policy concessions as a part of their overall strategy to get their way."

However, aside from anecdotal accounts about specific presidents and particular policy issues or from work on policy switching in the immediate aftermath of a presidential election (e.g., Stokes 2001), we still have no systematic comparative understanding of when, and to what degree, the executive in presidential systems is willing to compromise. Understanding this dynamic is directly related to the wider issue of governance and subsequent policy outcomes (see Saiegh 2009a, 1342). Although the assumption that presidents will compromise their policy position as part of their legislative

Christian Arnold (chriarno@mail.uni-mannheim.de) is an associate researcher at the Chair for Quantitative Methods of the University of Mannheim. 68131 Mannheim, Germany. David Doyle (david.doyle@politics.ox.ac.uk) is an associate professor of politics at the Department of Politics and International Relations, a fellow of the Latin American Center, and a fellow of St. Hugh's College, at the University of Oxford, OX1 3UQ, UK. Nina Wiesehomeier (nwiesehomeier@faculty.ie.edu) is a professor at the IE School of International Relations, Madrid, Spain 28006.

Data and supporting materials necessary to reproduce the numerical results in the paper are available in the JOP Dataverse (https://dataverse.harvard.edu /dataverse/jop). An online appendix with supplementary material is available at http://dx.doi.org/10.1086/688080.

The Journal of Politics, volume 79, number 2. Published online January 19, 2017. http://dx.doi.org/10.1086/688080

(c) 2017 by the Southern Political Science Association. All rights reserved. 0022-3816/2017/7902-0002\$10.00 
strategy is an important tenet of the revisionist literature, it remains undertheorized, primarily due to a lack of comparable data.

We address both issues in this paper. First, we contribute to the revisionist literature on executive-legislative relations (e.g., Amorim Neto 2002; Colomer and Negretto 2005; Cox and Morgenstern 2001; Raile et al. 2010) by providing an explicit theoretical account of the dynamics that undergird a president's willingness to compromise her policy position. We argue that the president does not adopt a static policy position across her term. Rather, the president, if she wishes to pursue a statutory legislative agenda, will respond to shifting dynamics in the house. Specifically, given the importance of the median party for such a statutory strategy, we contend that when the position of the median party changes, the president will shift her policy position in the same direction. When the president compromises her position in response to the median party in this manner, the president will enjoy a higher rate of success for her legislative initiatives than were she not to do so. The results of our empirical tests provide support for this assertion. Of course not all presidents will wish or need to compromise, and we expect that there will be notable heterogeneity to this dynamic. Indeed, our results show that the president's willingness to respond to the median party will depend on the president's nonstatutory power, her government status, and her ability to offset the need for compromise with increased material transfers.

Second, we address the current lack of adequate data. One of the primary obstacles toward a better understanding of these dynamics has been - to date-the difficulty of deriving reliable comparable estimates of the policy compromise of presidents over time. We understand executive policy compromise as positional flexibility on behalf of the president, which translates into presidential movement along a onedimensional issue axis. Using the scaling model Wordfish (Slapin and Proksch 2008) within a Bayesian framework, we estimate ideal points of 73 Latin American presidents on the basis of their strategically revealed positions in their annual state of the union addresses between 1980 and $2014 .^{1}$ The resulting data allow us to derive time-series data for presidential movements in a one-dimensional issue space, calculating the shift in policy positioning as the difference between a president's estimated position between time $t-1$ and time $t$.

1. Across Latin American countries, these types of speeches are named differently, such as Memoria del Gobierno, Informe del Gobierno - both translatable into "government report," Informe Presidencial (presidential report), or Estado de la Nación, the most equivalent to the state of the union address. Given that they serve an identical purpose across all countries, for the sake of simplicity, we will use the term "state of the union address" throughout this paper.
We therefore demonstrate the usefulness of speech data as a means to derive reliable and comparable ex post positional estimates for political actors over time and to provide the first comparable standardized measures of presidential movement across time and space for 13 Latin American countries. This is not only of interest to the literature concerned with measuring the policy positions of political actors across Latin America (Coppedge 1997; Micozzi and Kikuchi 2015; PELA 2005; Power and Zucco 2009; Saiegh 2009b; Wiesehomeier and Benoit 2009); it is particularly pertinent for studies of executive-legislative relations in a region where progress in scholarship is often hampered by data availability. Indeed, Latin America represents a difficult test for compromise: Latin American presidents are often caricatured as all powerful and imperial, and the region continues to suffer from high levels of presidential instability (Pérez-Liñán 2007). In many ways, the continent appears to continue to echo Linz's argument.

The remainder of this paper is organized as follows. The next two sections outline our main theoretical argument regarding the willingness of the executive in presidential systems to compromise her policy position. The fourth section introduces our method for estimating the policy positions of presidents and presents the annual position and relative movement of presidents in Argentina (1990-2014), Brazil (1986-2014), Chile (1990-2013), Colombia (1991-2013), Costa Rica (1983-2013), Ecuador (1982-2012), El Salvador (1995-2013), Guatemala (1999-2014), Mexico (1989-2013), Paraguay (1992-2011), Peru (1980-2013), Uruguay (200112), and Venezuela (1987-2014). The fifth section empirically explores the determinants of presidential movement across these 13 countries. The final section concludes.

\section{EXISTING EXPLANATIONS FOR POLICY SHIFTS}

While there is a large literature focusing on the adaption of party policy positions in response to public opinion (Adams, Haupt, and Stoll 2009), changing economic circumstances (Luna and Zechmeister 2005), the increasing salience of valence issues (Laver and Sergenti 2011), and the stickiness of party positions due to the nature of the party (Cox 1990) or electoral system (Dow 2001), surprisingly little work has focused on the movement of presidential policy positions. Evidence suggests, for single-country studies at least, that just like political parties, presidents may be responsive to public opinion and the electoral cycle (Calvo 2007). In the case of Latin America, presidents have radically changed their policy position in response to economic circumstances; this is best documented by the dramatic policy turns of newly elected presidents in the early 1990s (see Campello 2014; Kaplan 2013; Samuels and Shugart 2010; Stokes 2001). 
However, the majority of these arguments are concerned with explaining the ideological reorientation of the president in the immediate aftermath of a presidential election. But, just like political parties, presidents may experience similar incentives to adjust policy priorities throughout their time in office. Indeed, for a large portion of the revisionist comparative literature, which rejects the pessimism inherent in early interpretations of presidentialism, the ability of presidents to craft coalitions in support of their legislative agenda is not just solely about the distribution of cabinet seats (e.g., Amorim Neto 2006), or informal channels of negotiation (e.g., Mejía Acosta 2009), or the selective transfer of pork at key legislative moments (e.g., Raile et al. 2010), but also involves policy compromise with the legislature (e.g., Amorim Neto 2002; Cheibub 2007; Cox and Morgenstern 2001; Raile et al. 2010). Apart from some seminal work on the incentives for policy compromise during the process of coalition formation (Cheibub 2007; Colomer and Negretto 2005), we lack a comparative theoretical understanding of when and why a president will or will not compromise with the House throughout the course of her term in office. It is this gap that we address in the next section.

\section{PRESIDENTS AND POLICY COMPROMISE}

Given the separation of powers, independently elected presidents may not be bound to policy platforms held by their own party (Johnson and Crisp 2003; Wiesehomeier and Benoit 2009). As such, the independent preferences of presidents are crucial for policy making (Cheibub 2007; Kiewit and McCubbins 1991), and party positions and ideological cues from elections may poorly predict the policy priorities that presidents will adopt once in office. We argue that presidents in Latin American multi-party systems will adapt their policy position throughout the course of their term in response to the dynamic interplay of executive-legislative relations. ${ }^{2}$

We assume that the primary goal of the president is to govern, that is, to successfully enact policy (see Alemán and Tsebelis 2011; Saiegh 2009a, 1342), and, depending on her government status, she may have to build cross-assembly support to ensure the success of her legislative agenda (Alemán and Tsebelis 2011; Cheibub et al. 2004; Colomer and Negretto 2005; Negretto 2006). Presidential bargaining, both through material resources - such as the distribution of pork - and policy compromise, is thus essential, and it is the choices a president makes while in power that "foretell presidential success or failure [and that] ... matter a great deal" (Samuels 2008, 164). Therefore, presidents may find themselves confronted

2. As Cox and Morgenstern (2001) note, legislators will also adapt their position in response to the president. with situations in which they have to strategically decide to compromise their policy position in order to build support among legislators and to realize policy objectives.

We start with the assumption that the president has a preferred policy position on an underlying policy dimension, such as the traditional left-right axis, and that she seeks to improve the status quo of policy in line with her own preferences (see Strøm 1990). We also assume that the preferences of legislative parties as a whole can be located on this policy space. Once a president assumes office, she must reveal a policy position in the political arena. This displayed position will depend on her strategy, which will in turn depend on her own preferences, the preferences of others in the legislative arena, and the institutional context in which these actors interact. One of the choices presidents have to make when they come to power is to decide on a governing strategy, pursuing either a statutory strategy through the normal legislative process or an extra-legislative strategy through the exercise of unilateral legislative powers such as decrees (e.g., Carey and Shugart 1998). ${ }^{3}$ As Amorim Neto and Samuels (2011) point out, each of these strategies involves political parties to differing degrees, and thereby they also create different incentives for the executive to build relationships with legislative parties and to take into consideration the interests of legislators. Although independent from the legislature, presidents must engender majority support within the House if they are to succeed with a statutory legislative agenda. In this scenario, the median party along the policy space becomes crucial for policy making, as it represents the threshold for a legislative majority (Colomer and Negretto 2005, 77-78). Therefore, when the president assumes office, she will display a policy position that considers the assembly median, even though this position may or may not be her preferred ideological position (Cheibub 2007; Colomer and Negretto 2005). ${ }^{4}$ Indeed, Wiesehomeier and Benoit (2009) show that the median party in the legislature forms a focal point to which a president's position tends to be drawn.

However, what happens if during the course of a president's term the median party changes? For example, mid-term legislative elections might significantly alter the composition of the assembly or legislators may be wooed to a different party and cross the floor. If the president wishes to pursue her statutory policy-making agenda and achieve policy victories, then she must rebuild a legislative coalition and nar-

3. In reality, it is unlikely that presidents follow pure strategies; they will, of course, employ some mix of both.

4. It is simply not possible to ascertain the president's true preferred position. Election manifestos may provide some clues, but they will be written in response to electoral incentives. 
row the widening gap between herself and the median party position. By shifting her policy position and considering the new median party position, she can signal to legislators that she is willing to accommodate their positions, enabling the president to begin the process of reconstructing a legislative coalition in support of her agenda. ${ }^{5}$ In other words, anticipating the increased risk of policy conflict (Cox and Morgenstern 2001), shifting the policy position in response to the median party may be an effective means for a president to increase support for her policy goals, resulting in higher rates of statutory legislative success. Therefore, all else equal:

H1. When the median party changes, the president will move in the direction of this new median.

Yet, this is not to say that the median party will be a policy dictator. Rather, the pull of the median party in the legislature will be mediated by factors related to a president's inherent, that is institutional, and political strengths, and we therefore expect to observe a significant systematic heterogeneity to this effect. As pointed out before, the institutional context in which the actors operate will foster or dampen presidential incentives for positional shifts. Some presidents in Latin America, for instance, enjoy considerable unilateral institutional prerogatives. Strong presidents may therefore not have the need to shift their position - their agenda-setting power may override the need to compromise their preferred position in the first place (see Negretto 2004). As they will have the ability to circumvent the legislature and pursue an extra-legislative strategy, presidents who have the cards stacked in their favor do not have to rely on negotiating with the median party (containing the median legislator) to see their policy goals achieved. In other words, presidents with a favorable balance of power will be more prone to adapting an imperial governing strategy (Cox and Morgenstern 2001). ${ }^{6}$ What is more, when a president has high levels of executive power at her disposal, this may even entice legislators to move toward the president to neutralize the threat of an extra-institutional legislative strategy. Therefore:

5. Additionally, as Raile et al. (2010) argue, even in an environment where ideology is less important, it should still contribute to stability in legislative support for the executive.

6. This reasoning is akin to the impact of the balance of institutional power on a president's proclivity to form coalition governments (Alemán and Tsebelis (2011)), which of course also implies bargaining about policies. However, Samuels (2003) suggests that even when presidents can act unilaterally, they may refrain from doing so. Instead, they attempt to explicitly link legislators to national policy as a means of spreading the responsibility for national governance, thereby reducing their own accountability to the electorate.
H2. At high levels of executive power, we expect the president to shift her displayed policy position less in response to changes in the median party relative to presidents with weaker powers.

Equally, we expect that political factors that pertain to the president will weaken the presidential drift toward the legislative median. Recent comparative work on executivelegislative relations in presidential systems, particularly for the Latin American case, has emphasized the importance of the transfer of particularistic benefits, together with cabinet and public sector goods, to individual legislators and coalition partners, in order to build and maintain support for the executive's legislative agenda (Ames 2001; Amorim Neto 2002; Cox and Morgenstern 2001; Raile et al. 2010). Pork can be exchanged in return for votes and can help "overcome ideological resistance in generating legislative support" (Raile et al. 2010, 324). In this way, the transfer of material resources can offset the need for the president to compromise her policy position, enabling her to remain closer to her preferred position in the policy space. Hence, if the executive has the resources to engage in spending to secure necessary votes to push through her policies, then there should be less of a requirement for her to signal policy flexibility to the median party. Therefore:

H3. At high levels of targeted material transfers, we expect the president to shift her displayed policy position less in response to changes in the median party relative to lower levels of targeted transfers.

Presidents can also derive political strength from the separate election of the executive; for Linz (1990), in fact, this is one of the key dangers of presidentialism. As directly elected representatives of the nation, presidents may be able to claim to speak directly for the people, thereby claiming a "democratic, even plebiscitarian legitimacy" (Linz 1990, 53). Not only may this give rise to populism, particularly in contexts where the electorate may have little faith in existing institutions or parties (e.g., Doyle 2011), but when a president is very popular among the public, it may also allow her to ignore changes in the preferences of the legislature because these shifts do not truly represent the preferences of "the people." Indeed, evidence suggests that high public approval ratings can increase the bargaining power of the executive and bolster her legislative agenda (Calvo 2007; Carlin, Love, and Martínez-Gallardo 2014; Martínez-Gallardo 2011). In a similar vein, the honeymoon period may empower a newly inaugurated executive and lessen the incentive to accommodate her position as she carries the most recent popular mandate (Alemán and Navia 
2009; see also Calvo 2007; Figueiredo, Salles, and Vieira 2011). Therefore:

H4. At high levels of popular approval, we expect the president to shift her displayed policy position less in response to changes in the median party relative to lower levels of popular approval.

H5. During the honeymoon period, we expect the president to shift her displayed policy position less in response to changes in the median party.

Finally, as the comparative literature has also well established, the partisan power of the president will be crucial for interbranch bargaining (Mainwaring and Shugart 1997). When a president assumes power, she will either have a single-party majority, a single-party minority, or some form of minority or majority coalition. In general, we would expect presidents with a majority to move less relative to presidents with a minority. Yet, while a majority coalition does contain the median party, contrary to the situation of a single-party majority, a coalition legislative median may change, inducing presidential adjustment. For minority executives, our expectations are even less clear. On the one hand, it is possible that we see less positional flexibility for a minority executive because we are observing a case in which policy differences are large. In this scenario, policy compromise may simply be too costly for the president (Diermeier 2006), resulting in a minority government opposed by a hostile majority and "no one can do anything about it" (Cheibub et al. 2004, 566). Alternatively, a minority government may indicate an executive who opted against the formation of a long-term coalition, preferring instead to either set policies unilaterally or to form ad hoc alliances to enact her legislative agenda (Alemán and Tsebelis 2011; Cheibub et al. 2004; Negretto 2006). Consequently, we do not formulate clear directional hypotheses for government type but leave it open to empirical investigation. ${ }^{7}$ The next section will discuss the data we use to explore our propositions empirically.

\section{MEASURING THE POLICY POSITIONS OF PRESIDENTS}

Previous work estimating policy positions of political actors in Latin America has relied on a variety of sources, such as

7. We do acknowledge that there are of course additional factors that will affect the incentives of presidents to alter their revealed preference, such as economic crises (Stokes 2001). Here we just focus on the incentives for policy compromise generated by interbranch interaction. citizen placement from survey data (e.g., Latinobarómetro or country electoral polls), elite surveys (e.g., PELA 2005; Power and Zucco 2009), and expert surveys (e.g., Coppedge 1997; Wiesehomeier and Benoit 2009). While most of these efforts have focused on political parties, only a few of them consider the president as a self-contained actor and measure presidential positions separately (PELA 2005, Power and Zucco 2014; Wiesehomeier and Benoit 2009). However, even if they do, the data provided has limited temporal scope and only offers information about a single point in time, the position of the incumbent president at the time the respective survey was conducted.

Retrieving a time-series of presidential policy preferences via a survey instrument ex post may potentially be problematic as the responses may suffer from a temporal anchoring problem (see Saiegh 2009b). Another possibility to learn about elite policy preferences is the analysis of voting patterns in congress (Alemán and Saiegh 2007; Ames 2001; Carey 2008; Micozzi and Kikuchi 2015; Poole and Rosenthal 1997). Yet roll calls are often called upon for strategic purposes, which may introduce bias in any inference based on this data. In addition, presidents do not take votes in the legislature, which renders roll calls of limited use to determine the executive's policy preferences independently from that of her political party.

We overcome these empirical obstacles and present the first time series of presidential ideal points for 13 Latin American countries. We derive policy positions on the basis of the president's annual speech to congress about the current state of affairs. Like any other political actor, presidents express policy preferences through text. They aim at conveying a message, and consequently they reveal policy positions in speeches and written statements.

Using text offers one key advantage over alternative means: text and speech documents can always be analyzed ex post. Any revealed position can be retrieved for extended time periods, going further back into the past. Party election manifestos are a well-known data source in this respect (see Budge 2001), but increasingly scholars are also making use of other sources, such as government speeches (Brier and Hopp 2011; Klemmensen, Hobolt, and Hansen 2007) or legislative speeches (Hakhverdian 2009) to retrieve positional information on political actors. In the Latin American context, Murillo (2007), for instance, analyzes the speeches of presidents in Costa Rica, while Sagarzazu (2011) examines Brazilian legislative speeches. Thus, measuring the latent displayed policy positions of presidents with the help of computerized text analysis, we retrieve reliable data to calculate the presidents' movement in the issue space. 


\section{Annual presidential addresses in Latin America}

The texts we use to estimate annual presidential positional data are presidents' annual state of the union addresses. ${ }^{8}$ The delivery of this speech is highly institutionalized. Across all 13 countries included in our study, the constitution determines that the executive is required to periodically inform the congress about the country's situation. The primary target audience in these different national settings is the same: while these speeches may address noninstitutional actors such as the electorate, presidents will above all seek the support of legislators. ${ }^{9}$ It is an opportunity to garner support for the executive's course of action across all salient policy areas and to appeal to the median party. Given that these speeches are delivered annually, they enable us to capture this signaling by tracking positional movement over time.

Table 1 summarizes our sample of 305 speeches given by 73 presidents in 13 Latin American countries. In most instances, the first year of observation refers to the year of re-democratization of the respective country. In the case of Argentina, Colombia, Costa Rica, Guatemala, El Salvador, Uruguay, and Venezuela, the time period covered in our sample is restricted due to data availability. For Mexico, our observation period begins with the year 1989, as that year is considered to be the start of the nonauthoritarian regime (Hagopian and Mainwaring 2005). In the case of Peru, we exclude the period of Alberto Fujimori's self-coup from our analysis.

While the more recent documents could often be retrieved from official websites of the executive or the legislature, older speeches only existed as physical documents in the respective national archives. We transform all documents into a machine-readable format, relying on digitized sources where possible and scanning all hard-copies where necessary. To prepare the speeches for further analyses, we remove stopwords, special characters, and numbers, and we reduce the words to their stems. We count the occurrence of each word stem in each document and then build term-document matrices for each country.

Table 1 also highlights key characteristics of the texts for each country corpus. State of the union addresses in Brazil, Guatemala, and Uruguay stand out for being the shortest on average-we count only 1,650.76, 822.31, and 1,722.00 word stems, respectively. On the opposite end, we find the presidential addresses in Chile (7,792.38) and Venezuela (9,955.52)

8. It is important to note that the topics covered by the president in these speeches can also be strategic at times.

9. Unlike in the case of the United States, in Latin America, in only a small number of countries is the president's speech televised. with considerable average lengths. The standard deviations of these speeches indicate that the within-country variation generally does not reach high levels, the exception being Venezuela, driven by the late Hugo Chávez. The median relative frequency of the words allows us to get a snapshot of the most used vocabulary: unsurprisingly, presidents often refer to their own country, use words such as "country" (pais), and "year" (ano), and the expected technical terms like "government" (gobiern), "public," "social, or "development" (desarroll).

\section{Presidential positions in a latent issue space}

We measure the revealed annual presidential positions on the basis of the scaling model proposed in Slapin and Proksch (2008). ${ }^{10}$ The model expresses the occurrence of terms in a speech as a function of the political leaning of speakers and the ideological meaning of employed terms. Since our speeches cover an extended time period, changing or trending topics may affect the estimation as the scaling model retrieves the estimated positions on the basis of the word frequency only. If certain topics appear in a very limited number of speeches and the speaker tilts toward one side of the spectrum, the algorithm may wrongly identify the rare words as strongly separating between the end points of the one-dimensional axis. To address this problem, we follow Proksch and Slapin (2009) and use word stems that are mentioned in at least $20 \%$ of the documents.

The frequency of a term $j$ in a document $i$ is captured with the word frequency matrix $Y_{i j}$. The observed counts are the result of a probabilistic process and are therefore driven by a stochastic component, on the one hand, and a systematic component, on the other hand. To model the former one, we follow Däubler and Benoit (2013) and Lo, Proksch, and Slapin (2014) and express $Y_{i j}$ as the result of a negative binomial distribution.

$$
Y_{i j} \sim \operatorname{NegBin}\left(\mu_{i j}, \nu_{j}\right) .
$$

The exact shape of the probability distribution relies on the two parameters $\mu_{i j}$ and $\nu_{j}$. The parameter $\nu_{j}$ captures heterogeneity. ${ }^{11}$ We let it vary according to

$$
\nu \sim \operatorname{Gamma}(\rho)
$$

where $\rho$ is a parameter that determines the gamma distribution (Cameron and Trivedi 2013).

10. For the growing literature on statistical approaches to measure content and preferences expressed in textv, see Grimmer and Stewart (2013), Laver, Benoit, and Garry (2003), Laver and Garry (2000), and Slapin and Proksch (2008).

11. The parameter $\nu_{j}$ is of less theoretical concern in this application. But see Lo et al. (2014) for an explicit treatment. 
Table 1. State of the Union Addresses in Latin America: Countries, Time Periods, and Key Characteristics

\begin{tabular}{|c|c|c|c|c|}
\hline \multirow[b]{2}{*}{ Country } & \multirow[b]{2}{*}{ Time Period } & \multicolumn{2}{|c|}{$\begin{array}{l}\text { Number of Words } \\
\text { in the Address }\end{array}$} & \multirow[b]{2}{*}{ Top Eight Most Frequent Words (Median Relative Frequency) } \\
\hline & & Mean & SD & \\
\hline Argentina & $1990-2014$ & $4,521.12$ & $2,952.11$ & argentin, hac, millon, nacional, pais, polit, social, trabaj \\
\hline Brazil & $1986-2014$ & $1,650.76$ & $1,103.93$ & brasil, congress, econom, govern, nacional, pais, polit, tod \\
\hline Chile & $1990-2013$ & $7,792.38$ & $2,521.46$ & ano, chil, chilen, gobiern, mejor, nuev, pais, trabaj \\
\hline Colombia & $1991-2013$ & $3,159.83$ & $1,108.43$ & colombi, congres, gobiern, nuev, pais, polit, segur, social \\
\hline Costa Rica & $1983-2013$ & $4,292.48$ & $1,594.09$ & cost, costarricens, desarroll, gobiern, mejor, nuev, pais, ric \\
\hline Ecuador & $1982-2012$ & $5,964.21$ & $1,788.69$ & ano, ecuador, ecuatorian, gobiern, millon, nacional, pais, polit \\
\hline El Salvador & $1995-2013$ & $2,396.38$ & 779.25 & ano, desarroll, gobiern, nacional, nuev, pais, salvadoren, social \\
\hline Guatemala & 1999-2014 & 822.31 & 836.71 & administracion, desarroll, gobiern, nacional, pais, polit, republ, social \\
\hline Mexico & $1989-2013$ & $5,414.84$ & $2,929.26$ & ano, gobiern, mexic, mexican, millon, nuev, pais, polit \\
\hline Peru & $1980-1991,1996-2013$ & $4,797.38$ & $2,912.42$ & gobiern, millon, nacional, nuev, pais, peru, sol, trabaj \\
\hline Paraguay & $1992-2011$ & $4,021.65$ & $1,662.18$ & desarroll, gobiern, nacional, nuev, pais, paraguay, polit, social \\
\hline Uruguay & $2001-12$ & $1,722.00$ & 589.49 & ano, gobiern, mism, nacional, pais, polit, public, uruguay \\
\hline Venezuela & $\begin{array}{c}1987-93,1995-99 \\
2001-12,2014\end{array}$ & $9,955.52$ & $7,387.21$ & ano, gobiern, hac, nacional, pais, social, venezolan, venezuel \\
\hline
\end{tabular}

Note. We remove stopwords and consider wordstems only. The length of a speech is measured in words. For Peru, the period of Alberto Fujimori's self-coup has been excluded. Missing years for Venezuela indicate data restrictions/years for which the speeches were not available.

However, recall that the main interest is to understand the expected value $E\left[y_{i j}\right]$ of our count matrix. The parameter $\mu_{i j}$ is a key component since it expresses the first moment of the probability distribution $E\left[y_{i j} \mid \mu_{i j} \nu_{j}\right]=\mu_{i j}$. We formulate the parameter $\mu_{i j}$ as the result of a systematic component.

$$
\mu_{i j}=\exp \left(\alpha_{i}+\psi_{j}+\omega_{i} \times \beta_{j}\right)
$$

Each document $i$ has idiosyncratic characteristics that determine the occurrence of a particular term $\alpha_{i}$. In a similar vein, $\psi_{j}$ captures the idiosyncratic characteristic of each term $j$. The key mechanics of the model is the interaction between $\omega_{i}$ and $\beta_{j}$. The parameter $\omega_{i}$ captures the value we are ultimately interested in: the ideological position of a document $i$. This position is weighted with the ideological leaning of words $\beta_{j}$.

We maximize the model for each country's speeches in a Bayesian framework, meaning we retrieve the most likely values for the models' stochastic and systematic parameters given the observed frequencies $Y_{i j}{ }^{12}$ Note that as a result the

12. We identify our estimates by setting $\alpha_{1}=0$ (Däubler and Benoit 2013; Slapin and Proksch 2008). Priors are uninformative with $\nu_{j} \sim$ Gamma $(0.02 ; 0.02)$ and for all other stochastic nodes Normal $\sim(0 ; 25)$. We use parallel chains with overdispersed starting values until mixing between, and convergence within, the chains reach acceptable levels. Once estimated, we adapt the signs of each time series to sync the latent dimension with a broadly perceived one-dimensional left-right space. model determines the relative position of the documents as well as the ideological content of the terms. While we are primarily interested in the ideological position of the speeches, we retrieve the ideological value of the term $i$ as a by-product of the estimation process, too. For example, in Ecuador, we find among the 15 ideologically most relevant terms on the one side of the spectrum the word stems ancestral, asambl, asesin, companer, corazon, mentir, miseri, planet, prens, revolucion, revolucionari, and victori-these are all terms a strongly leftleaning speaker would typically use. On the other side, we find terms much more related to a liberal, conservative ideology, such as afianz, aprobacion, consorci, ejecutor, ferrocarril, innfa, instalacion, previs, rios, socioeconom, and terminacion.

Figure 1 displays the resulting $\omega_{i}$ with a heatmap. Each country's time series reports standardized $z$-scores and progresses from the earliest speech available in our sample on the left to the most recent observation on the right. The shading of the cells reflect the estimated ideal point; more negative values are shown in darker shading, increasingly becoming lighter with more positive values. Note that absolute positions can only be compared within a country. Cross-country comparisons are only possible for presidential movements because standardization per country expresses movements relative to the stretching of the respective main political dimension. For example, a shift from a displayed position at -1 to +1 can be interpreted as a movement of two standard deviations around the mean position of a country's political spectrum. 


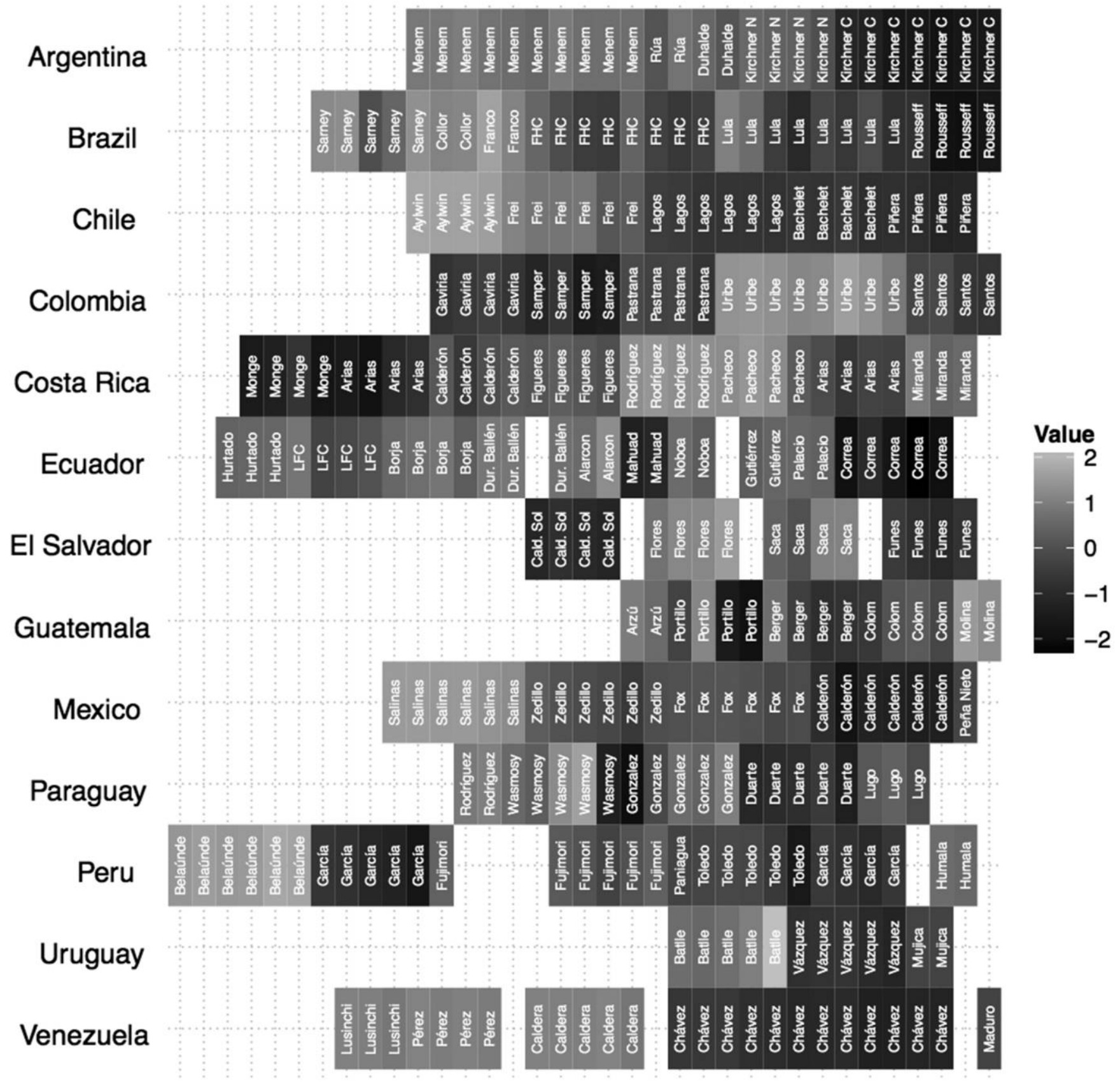

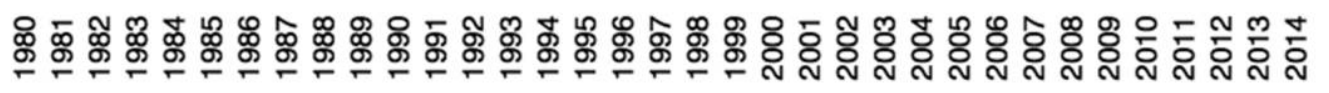

Figure 1. Posterior means for the latent ideal-points in 13 Latin American countries. Values are standardized, countrywise $z$-scores

Our estimates suggest that countries can be loosely grouped into three broad categories. In some cases, presidents themselves tend to display similar and stable political views, but we find a remarkable difference between presidents. Executives in Colombia, Costa Rica, Uruguay, and also Venezuela can be considered to fall into this category. For example, all of the speeches of Colombia's former president, Álvaro Uribe, reveal policy positions that are quite consistently to the far right. In Costa Rica, the ideal points of individual presidents also tend to cluster, and the late Hugo Chávez in Venezuela is clearly distinct from all his predecessors. In contrast, in Argentina, Chile, and Mexico, the presidents' movements appear to trend over time. While early presidents begin at one end of the spectrum of the issue space, the more contemporary executives display ideal points that are at the opposite end of the spectrum. The remaining countries can be roughly sub- 
sumed into one last category. Here, incumbents differ in their displayed attitudes, resulting in political systems with a high mobility of presidents along the latent issue dimension.

\section{Robustness and validation}

We implement a series of robustness checks to validate our results (Grimmer and Stewart 2013), all of which can be found in the appendix, available online. First, a concern relates to the identification of the model. Presidents may tend to take central positions in a unidimensional issue space or they may occupy only parts of the overall issue space in a country. We explore this possibility of truncation by identifying the model with externally valid "anchors" based on positional data elicited by the elite surveys of the PELA project (PELA 2005). We use this information to fix our model in the issue space, correcting for the respondents' individual scale and stretch factors, as suggested by Aldrich and McKelvey (1977). The differences are minor.

Second, when texts span a long range of time, changing topics may affect the estimation of the ideal points. As pointed out, we follow Proksch and Slapin (2009) and estimate all our results with word stems that appear in at least $20 \%$ of the texts, but as an additional test, we re-estimated our models with word stems that appear in at least $30 \%$ and $40 \%$ of the texts. ${ }^{13}$ Again, the differences are minor.

Third, it is difficult to validate our results, given that no comparable measures of executive policy positions across Latin America over this time period are currently available. Wiesehomeier and Benoit (2009) provide a cross section of ideology scores for 18 executives based on an expert survey. The correlation with our measure is 0.42 for 2006. Power and Zucco (2014), in the last wave of the Brazilian Legislative Survey, asked legislators to retrospectively assign a score to past Brazilian presidents on the economic left-right dimension. This is a single score per president and not a time series, but nonetheless, the correlation with our measure is 0.75 .

Finally, and more significantly, our estimates do seem to be capturing some latent underlying left-right dimension. Existing work has shown that left-leaning governments across Latin America are associated with higher levels of social spending relative to right and centrist administrations (Kaufman and Segura-Ubiergo 2001; Pribble 2013). In a regression model predicting variation in levels of social spending, our estimates are statistically significant at the .01 level. ${ }^{14}$ According to this

13. Given that these particular estimates could be an artifact of topic trending, we report the results for Chile, as an example, in the appendix.

14. These are estimated with country fixed effects. Please see the appendix. model, our most right-leaning executive is associated with a predicted level of social spending of $11.81 \%$ of GDP. In contrast, our most left-leaning executive has a predicted level of social spending of $13.57 \%$ of GDP.

\section{THE MEDIAN PARTY, POLICY COMPROMISE, AND LEGISLATIVE SUCCESS}

With these estimated policy positions, we can now test our theoretical propositions. The results of these tests can be found in table 2. The dependent variable in each model in this table is the degree of movement in the policy space. For each president, we calculate the respective directional movements as the difference between the position of a president at a point in time $t$ and her position in the previous period, $t-1 .{ }^{15}$ This allows us to calculate whether a president shifted to the left or to the right, and to what extent, for each year of her term. ${ }^{16}$

Our main independent variable is change in the legislative median. We collect annual data for the composition of the legislature for a date just prior to each state of the union address. ${ }^{17}$ We then assign $n \_k$ legislators a party ideology score on a 1-20 scale, where 1 is left and 20 right, based on the expert survey data of Coppedge (1997), Pop-Eleches (2008), and Wiesehomeier and Benoit (2009); $n$ represents the number of legislators for each party, $k$. Ordering the legislators in each country from left to right, we then calculate the median

15. It should be noted that these movements are comparable across both time and space. First, any absolute anchor becomes obsolete because it cancels out when calculating the difference between two ideal points. Second, since we standardize the ideal points to $z$-scores within each country, we take account of any stretching of the movements. We interpret any movement as a movement relative to the overall issue space within each country.

16. In Colombia, Costa Rica, Ecuador, Mexico, Peru, Paraguay, and Uruguay, presidents made their final state of the union address on the first day of the new legislature. For example, in Costa Rica, the president makes her last address each year on May 1, which is also the day when the new legislature takes their seats. As this often implies a change in the median party while a president in this case is not addressing "her" legislature, this last speech is therefore excluded from our analysis. We also exclude the two extreme cases of Paraguay 1998 and Guatemala 2003 from further analyses as these speeches were held in years of extreme national tensions. In Paraguay, this was a post-coup attempt atmosphere; in Guatemala, the backing of the ex-military ruler Montt as candidate by the incumbent president led to intense violent conflicts and even a day of besiegement of Guatemala City in July. As a robustness check, we also re-ran all models without Venezuela after 2000. The results hold.

17. Given that party switching is quite common in some Latin American countries, we contacted each country's Library of Congress and requested these data. We received this annual information for a number of countries, but we did not receive any responses for the requested data from Argentina, Guatemala, Paraguay, and Venezuela. For these countries, we collected the data from election archives and various sources on the Internet. A full list of all median parties, by year, can be found in the appendix. 
Table 2. The Incentives for Executive Movement

Median party position

$\Delta$ Median party position

Policy position t-1

$\Delta$ Party position $\times$ Position $_{t-1}$

Presidential power

$\Delta$ Party position $\times$ Presidential power

Presidential approval

$\Delta$ Party position $\times$ Approval

Administrative spending

$\Delta$ Party position $\times$ Spending

Honeymoon

$\Delta$ Party position $\times$ Honeymoon

Constant

$N$

$R^{2}$

Note. All models are estimated with country fixed effects. Robust standard errors are in parentheses.

${ }^{*} p<.05$.

${ }^{* *} p<.01$.
$(1)$ $.152^{* *}$

(2)

(3)

(4)

(5)

(6)

(7)

$(.02)$

\begin{tabular}{|c|c|c|c|c|c|}
\hline \multirow{22}{*}{$\begin{array}{c}-.078^{*} \\
(.04)\end{array}$} & -.034 & .114 & .009 & $.442^{*}$ & $-.078^{\star}$ \\
\hline & $(.04)$ & $(.07)$ & (.18) & & $(.04)$ \\
\hline & $-.073^{*}$ & & & & \\
\hline & $(.03)$ & & & & \\
\hline & .038 & & & & \\
\hline & $(.03)$ & & & & \\
\hline & & -.470 & & & \\
\hline & & $(.28)$ & & & \\
\hline & & $-.333^{\star *}$ & & & \\
\hline & & (.10) & & & \\
\hline & & & -.001 & & \\
\hline & & & $(.00)$ & & \\
\hline & & & -.001 & & \\
\hline & & & $(.00)$ & & \\
\hline & & & & .004 & \\
\hline & & & & $(.02)$ & \\
\hline & & & & $-.039^{*}$ & \\
\hline & & & & $(.02)$ & \\
\hline & & & & & -.004 \\
\hline & & & & & $(.07)$ \\
\hline & & & & & .000 \\
\hline & & & & & (.07) \\
\hline-.032 & -.047 & 199 & .049 & -.120 & -.031 \\
\hline$(.06)$ & $(.06)$ & (.15) & (.19) & $(.21)$ & $(.06)$ \\
\hline 189 & 189 & 189 & 123 & 189 & 189 \\
\hline .127 & .157 & . 147 & .163 & .158 & .127 \\
\hline
\end{tabular}

party ideology score for each legislature and for each year. We calculate any changes in the median as the difference in the ideological score of the median party at a point in time $t$ and the position in the previous period, $t-1$.

To account for hypotheses $2-5$, we include a measure of the institutional power of the executive from Doyle and Elgie (2016); the mean rate of public approval for a given president in a particular year (from Carlin et al. 2014); a proxy for targeted spending, general government final consumption expenditure as a percentage of GDP, which includes all government current expenditures for purchases of goods and services, including compensation of employees (which comes from the World Bank's World Development Indicators); a dummy variable if a president is the first year of her term, to capture any honeymoon effect (see also Calvo
2007; Figueiredo et al. 2011); and finally, a series of separate dummies for government type, single party minority and majority or minority coalition (based on data from the World Bank Dataset on Political Institutions, updated in January 2013; Beck et al. 2001). ${ }^{18}$ Given the expected conditioning effect of these variables, we interact each one with the change in the policy position of the median party.

As we can see from model 1 in table 2 , there is a very strong relationship between the ideological score of the median party and the position of the president. When the median

18. We also included a variety of economic controls, including inflation, GDP growth, trade as a percentage of GDP, debt service as a proportion of gross national income ,and participation in an IMF agreement. The results remain unchanged. 
party is to the right, so is the president's, and vice versa. Looking into the dynamics of this relationship, however, the results do not completely confirm our expectations. In fact, according to model 2, when the median party changes, then, all else equal, the president appears to move in the opposite ideological direction. When, in a first step, we explore this effect inductively by interacting our main independent variable with the policy position of the president at time $t-1$ (model 3), it appears that it is driven primarily by presidents on the left. Unsurprisingly, centrist presidents are most attuned to changes in the legislature; when the median party shifts left or right, so too do presidents in the center. ${ }^{19}$ This flexibility echoes arguments in the literature that centrist presidents may be able to achieve policy outcomes without entering formal cabinet coalitions (see Alemán and Tsebelis 2011), while more extreme presidents tend not to foster coalitions (see Amorim Neto 2006).

More important, however, figure 2 displays, from the topleft and moving counter-clockwise, the conditioning effect of presidential power, targeted spending, honeymoon periods, and presidential approval, respectively. As the top-left pane shows, with an unfavorable balance of power, executives in Latin America are willing to respond to dynamics within the house. When the position of the median party changes to the left or to the right, so too does that of the president. This makes sense as weak presidents will have no other option but to legislate through the house, and so they will be more attuned to dynamics among legislative parties. Strong presidents, however, appear to have no such compulsion. The effect of presidential power is statistically significant for shifts of the median party both to the left and to the right. Echoing long-standing concerns regarding strong presidencies (Shugart and Carey 1992), these results suggest a proclivity toward conflict when the president has recourse to significant institutional power in the context of changes of the legislative median away from the president's position (see also MartínezGallardo 2011).

Targeted spending, as expected, also appears to condition the executive's willingness to compromise her position. At high levels of spending, the president is no longer responsive to changes in the house, indicating that, as suggested by Raile et al. (2010), targeted spending does offset the need for ideological compromise. In contrast, at low levels of spending, presidents are quite responsive to the house, and when the median party shifts to the left or to the right, so too does the president. Honeymoon periods exert a similar effect, al-

19. The marginal effects of models 2 and 3 can be found in the appendix. though this effect is weak and only statistically significant in cases where the median party changes to the right. In this scenario, however, the honeymoon period appears to facilitate a less consensual approach from the president. Finally, varying levels of popular approval do not appear to have any notable effect.

To probe the effect of different levels of assembly support, we also interacted changes in the position of the median party with a dummy variable for each of the three relevant government types. ${ }^{20}$ The results of these models are displayed in figure 3. As we may expect, when the president's coalition commands a majority in the assembly, we do not observe any significant or notable change in the position of the president. In contrast, presidents in a minority situation, particularly presidents relying on a minority coalition, are more likely to adopt a conflictual stance with the house. When the house moves left, the president moves right, and vice versa.

Since we might expect minority presidents to actually anticipate the legislature and be willing to bargain with the house in order to build a majority on an issue-by-issue basis and get legislation passed (Alemán and Tsebelis 2011; Cheibub et al. 2004; Cox and Morgenstern 2001; Negretto 2006), at a first glance, this result appears counterintuitive. Yet, as we have argued, the institutional and political capacity of the executive will shape the strategies they employ. Splitting the sample at the median level of executive power is thus illuminating. ${ }^{21}$ The seemingly counterintuitive result we observe for minority presidents is entirely driven by strong presidents. There are no cases of weak presidents commanding minority coalitions, and for single party minority presidents with low levels of institutional power, the effect disappears. It would appear then that minority presidents with high levels of formal executive authority prefer to adopt an imperial strategy using unilateral action to pass legislation and to relate "to congress more as English monarchs used to relate to their parliaments" (Cox and Morgenstern 2001, 182). This finding not only reflects work warning of the substitutability of partisan support in presidential systems with high levels of executive prerogatives, but it is also consistent with prior work on presidential coalition formation behavior, which has argued that high levels of executive power decrease presidential incentives to form coalitions (see Alemán and Tsebelis 2011).

Our analysis of the factors that might mediate presidential policy compromise has highlighted that presidents engage to differing degrees in positional movement in the pol-

20. We did not include single-party majority, as by definition under this scenario the median would remain the same.

21. These results can be found in the appendix. 

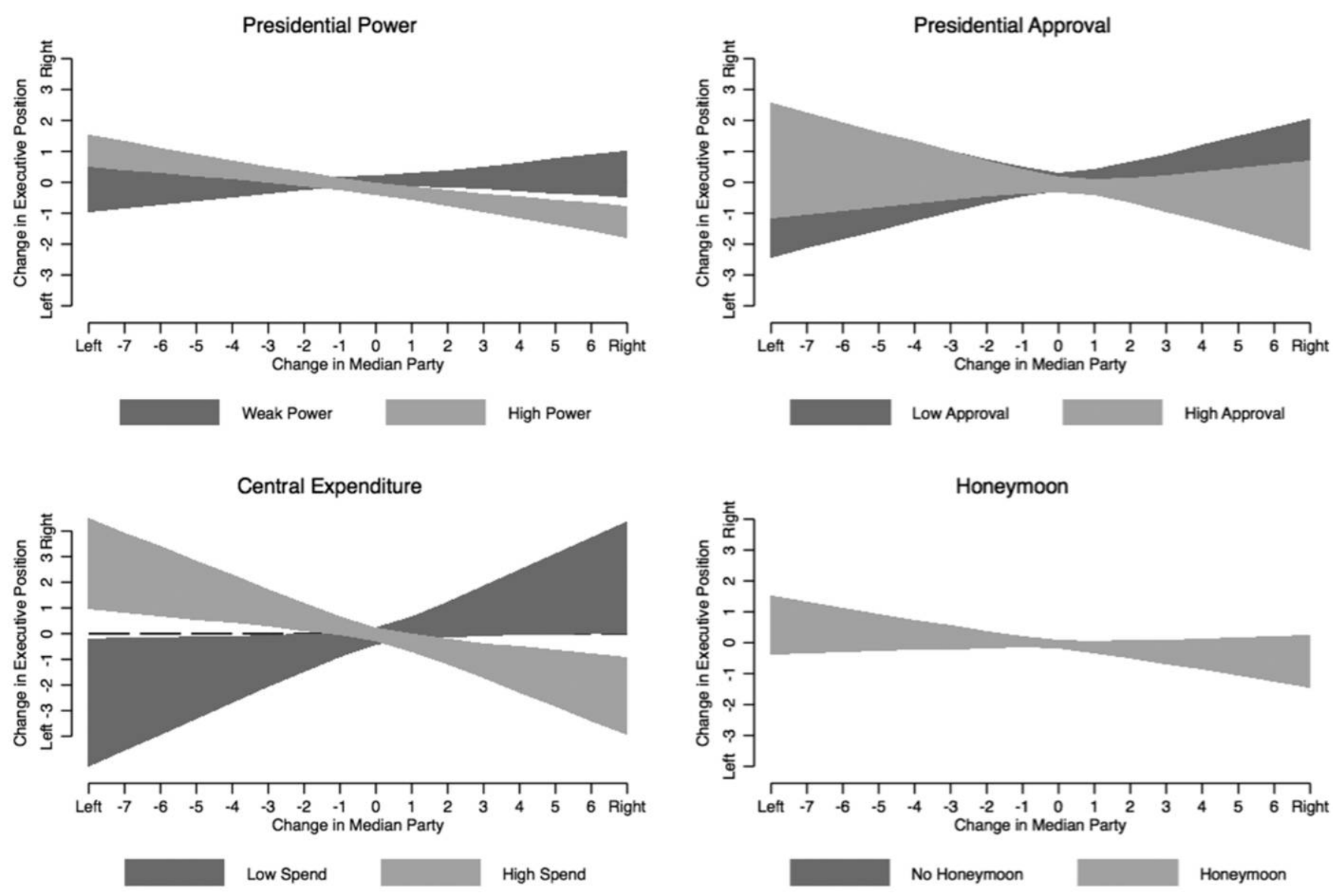

Figure 2. Conditioning effects on presidential compromise

icy space, conditional on the legislative environment in which they operate. The basic assumption underlying this analysis is that, in general, if the president does not have recourse to institutional power or large amounts of funds for targeted spending, then she must compromise and work with the assembly to implement policy. We should therefore expect to observe that presidents who move in response to changes in the house will have a higher rate of statutory legislative success in comparison to those that do not. That is, there will be some pay-off for responding to changes in the median party. Table 3 presents some evidence that this appears to be the case. As they cover slightly different time periods, we use two different dependent variables in this analysis: in models 1-4, we use the percentage of executive-initiated statutory bills passed by the lower house of the national legislature from Saiegh (2011), and in models 5-8, we use a similar measure taken from Montero (2009). ${ }^{22}$ It should be pointed out, however, that due to data availability, our number of cases drops dramatically. Our main independent variable is a dummy var-

22. We would like to thank Sebastián M. Saiegh and Mercedes García Montero for generously agreeing to share their data with us. iable coded as 1 if the president moves in the same direction as the median party when the median party changes, and 0 otherwise. When a president responds to dynamics in the house, then her rate of legislative success jumps. In other words, when the house moves left, and a president moves left also, then the rate of legislative success increases. In fact, whether a president chooses to respond to dynamics in the house or ignore any changes corresponds to a difference in their predicted rate of legislative success of approximately $6 \%$. Taken as a whole, therefore, these results suggest that positional compromise on the part of presidents can be an integral part of their legislative strategy.

\section{CONCLUSION}

The relative dangers of presidentialism as a form of government have long inspired debate (Bagehot [1867] 1964; Linz 1990; Stepan and Skach 1993). More recently, a revisionist comparative literature has challenged the assertion that presidentialism is more prone to legislative deadlock and executivelegislative conflict than other systems of government (e.g., Cheibub 2007; Cheibub et al. 2004; Negretto 2006). The core conclusion of this work suggests that presidents are far more 

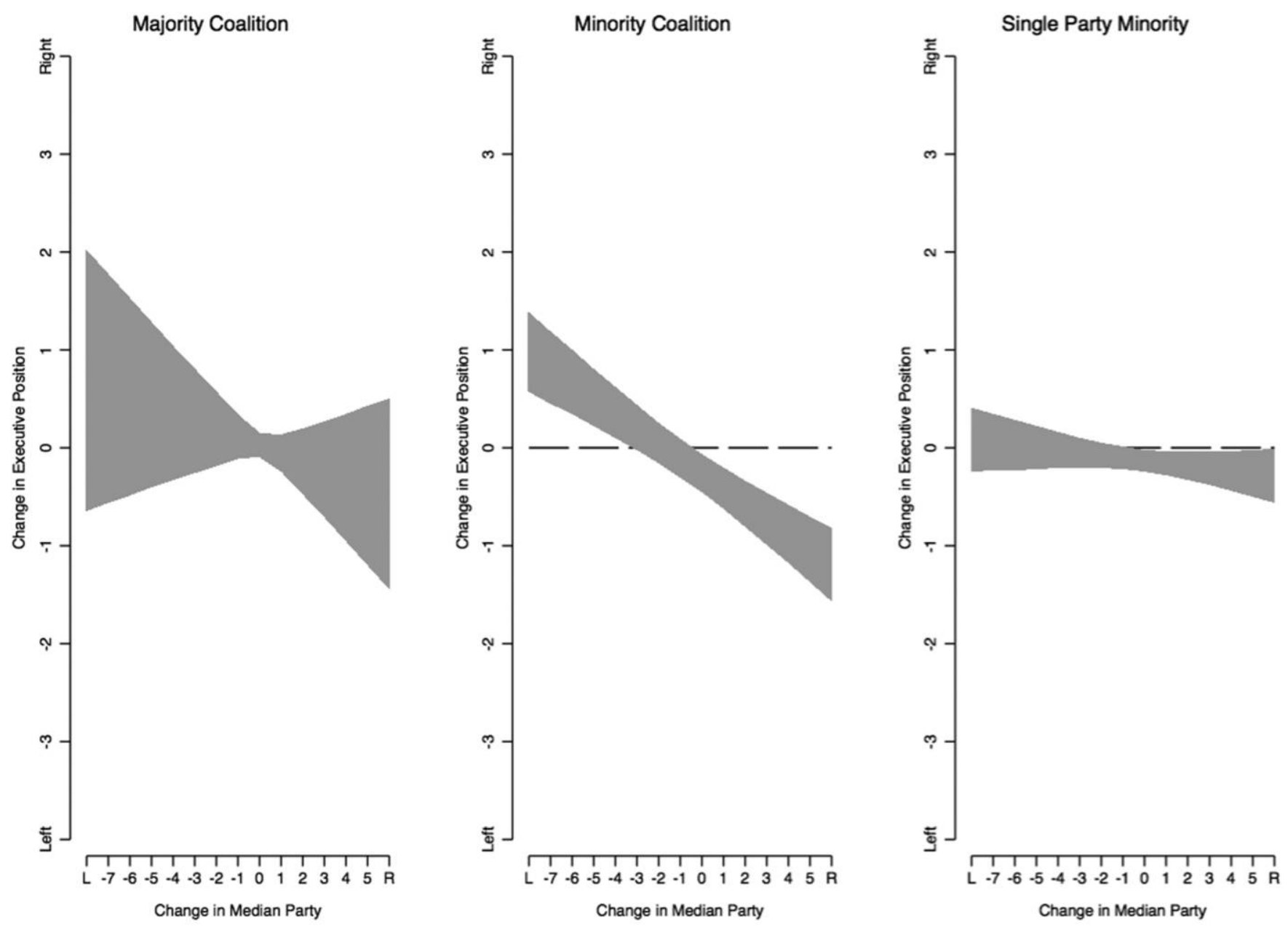

Figure 3. The conditional effect of government type

willing to compromise and work with legislators than initially thought. However, to date - and to the best of our knowledge - no extant study has attempted to explore the conditions under which presidents will signal this willingness and whether this indeed results in an improved legislative track record. We remedy this situation in two important ways.

First, we overcome previous empirical obstacles that prevented an analysis of these dynamics. Using annual state of the union addresses, we generate the first cross-national timeseries data on revealed positions, and relative movement, of 73 Latin American presidents between 1980 and 2014. This not only adds to the literature that attempts to measure the policy positions of political actors across Latin America (Coppedge 1997; Micozzi and Kikuchi 2015; PELA 2005; Power and Zucco 2009; Saiegh 2009b; Wiesehomeier and Benoit 2009), but more importantly it demonstrates the utility of speech data as a means of deriving ex post positions of Latin American political actors. We believe these data will be a valuable resource for comparative scholarship of Latin American politics.

Second, we contribute to the wider comparative literature on executive-legislative relations. These data allow us to establish when and to what degree a president will engage in positional compromise with the assembly during the course of her term. Specifically, what we demonstrate is that presidents will only compromise with the house when they are unable to draw on institutional powers or to build legislative coalitions with pork and targeted transfers. When the executives have recourse to these prerogatives, presidents actually tend to be more hostile than consensual toward the assembly. This pattern is particularly pronounced in minority government situations.

Our results thus further qualify our understanding of the dynamics in presidential systems. They suggest that the Linzian interpretation of presidentialism is probably too pessimistic. Presidents in Latin America are not always the inflexible and imperial leaders previously characterized by Linz. 
Table 3. Executive Movement and Legislative Success

\begin{tabular}{|c|c|c|c|c|c|c|c|c|}
\hline & (1) & (2) & (3) & (4) & (5) & (6) & (7) & (8) \\
\hline Move with party & $\begin{array}{c}1.428 \\
(5.34)\end{array}$ & $\begin{array}{c}2.345 \\
(6.03)\end{array}$ & $\begin{array}{l}5.884^{* *} \\
(1.56)\end{array}$ & $\begin{array}{l}6.502^{*} \\
(2.84)\end{array}$ & $\begin{array}{l}6.785^{* *} \\
(1.62)\end{array}$ & $\begin{array}{l}7.412^{*} \\
(2.81)\end{array}$ & $\begin{array}{l}5.028^{*} \\
(2.08)\end{array}$ & $\begin{array}{r}-1.102 \\
(4.22)\end{array}$ \\
\hline Power & & $\begin{array}{r}-91.463 \\
(45.81)\end{array}$ & & $\begin{array}{r}-104.252 \\
(53.04)\end{array}$ & & $\begin{array}{r}81.280 \\
(67.99)\end{array}$ & & $\begin{array}{l}126.435^{*} \\
(58.73)\end{array}$ \\
\hline Spending & & $\begin{array}{l}.793 \\
(.79)\end{array}$ & & $\begin{array}{l}1.329^{*} \\
(.54)\end{array}$ & & $\begin{array}{l}-.866 \\
(1.38)\end{array}$ & & $\begin{array}{r}.049 \\
(1.35)\end{array}$ \\
\hline Honeymoon & & $\begin{array}{r}.350 \\
(4.42)\end{array}$ & & $\begin{array}{c}1.178 \\
(3.91)\end{array}$ & & $\begin{array}{l}-.464 \\
(3.58)\end{array}$ & & $\begin{array}{r}-1.052 \\
(3.94)\end{array}$ \\
\hline Approval & & $\begin{array}{c}-.399^{*} \\
(.20)\end{array}$ & & $\begin{array}{c}-.520 \\
(.32)\end{array}$ & & $\begin{array}{l}.047 \\
(.16)\end{array}$ & & $\begin{array}{l}.954^{\star *} \\
(.31)\end{array}$ \\
\hline Constant & $\begin{array}{l}56.464^{\star *} \\
(3.50)\end{array}$ & $\begin{array}{l}107.228^{\star *} \\
(20.52)\end{array}$ & $\begin{array}{c}57.900^{\star *} \\
(.00)\end{array}$ & $\begin{array}{l}130.426^{\star *} \\
(42.18)\end{array}$ & $\begin{array}{l}61.367^{\star \star} \\
(5.03)\end{array}$ & $\begin{array}{c}29.133 \\
(33.42)\end{array}$ & $\begin{array}{c}68.750 \\
(.)\end{array}$ & $\begin{array}{r}-59.941 \\
(44.73)\end{array}$ \\
\hline Country FE & Yes & Yes & No & No & Yes & Yes & No & No \\
\hline President FE & No & No & Yes & Yes & No & No & Yes & Yes \\
\hline$N$ & 76 & 63 & 76 & 63 & 85 & 70 & 85 & 70 \\
\hline$R^{2}$ & .761 & .742 & .891 & .886 & .401 & .380 & .661 & .681 \\
\hline
\end{tabular}

Note. $\mathrm{FE}=$ fixed effects. Robust standard errors are in parentheses.

${ }^{*} p<.05$.

${ }^{*} p<.01$.

However, they also show that, under certain circumstances, they can be. In particular, our findings that pertain to the antagonistic nature of strong presidents in minority situations confirm previous work on the impact of institutional design on the performance of presidential regimes (Mainwaring and Shugart 1997; Shugart and Carey 1992). In other words, institutional variation among separation of power systems will condition the degree of harmony between the executive and legislative branches.

The flip side of the coin is, of course, that presidents are willing to compromise given the right institutional incentives. Our results show that a president can influence the interbranch relationship with signals of policy compromise and that when a president assumes office, in addition to the formal legislative tools at her disposal, she can also make use of a number of "efficient secrets" that can help manage her relationship with the house and ensure the success of her statutory legislative agenda (see, e.g., Figueiredo and Limongi 2000; Mejía Acosta 2009). Our results on policy compromise are indicative of this interbranch legislative dynamic that helps the president to build and maintain coalitions and to pass legislation in the house.

Institutional incentives are thus crucial for governance (Saiegh 2009a) in separation of powers systems, and it is important for how we might design constitutions in such systems to mitigate interbranch conflict and facilitate law- making. Of course, given that a president is directly elected, such policy shifts may undermine the quality of representation. In many Latin American democracies, faith in political institutions is already at a low point, and if executives engage in wide-ranging policy shifts in response to incentives in the assembly, then such moral hazard in the principal-agent chain will further erode the popular legitimacy of the political system (see Strøm, Müller, and Bergman2003). This is probably where some sort of trade-off exists between representation and effective governance. However, given the low number of observations for the executive's rate of legislative success, future research should delve in more detail into more casespecific conditions and aim at disentangling the incentives for presidents to signal a willingness to compromise on some issues but not on others.

\section{ACKNOWLEDGMENTS}

The collection of the speeches would not have been possible without the support of the staff at the national archives and libraries of Congress in the respective countries and of a fair number of individuals. In particular, we would like to thank Isabelle Arnold, Carlos Arroyo, Santy Barrios, Erika Biagini, Evangelina Cabrera Portillo, Daniel Chasquetti, Shatterson Cuello Felix, Luis Fretes, Alan Marcelo Henriquez, Ricardo Lopez Valverde, David Mantilla, Tomás Manzano Fraile, David Orozco, Simon Pachano, Germán Rios, Oscar Ronaldo 
Sierra Pop, Manisha Sabharwal, Junior Felix Santana Rojas, Glaucio Soares, Douglas Vargas, Francisco Vidal, and Teresa Zelaya. We gratefully acknowledge the helpful comments on earlier drafts of Ignacio Arana, Kenneth Benoit, Alexander Herzog, Evelyn Huber, Benjamin Lauderdale, Thomas Meyer, Juan Pablo Micozzi, Timothy Power, Sven-Oliver Proksch, Guillermo Rosas, Elizabeth Zechmeister, Cesar Zucco, and the editor and anonymous reviewers of the Journal of Politics. Finally, we would like to thank Ryan Carlin for generously sharing data on presidential approval and John PolgaHecimovich for generously sharing data on presidential decrees.

\section{REFERENCES}

Abranches, Sérgio. 1988. "Presidencialismo de coalizão: o dilema institucional Brasileiro." [Coalitional presidentialism: The Brazilian institutional dilemma.] Dados 31:5-38.

Adams, James, Andrea B. Haupt, and Heather Stoll. 2009. "What Moves Parties? The Role of Public Opinion and Global Economic Conditions in Western Europe." Comparative Political Studies 42:611-39.

Aldrich, John H., and Richard D. McKelvey. 1977. "A Method of Scaling with Applications to the 1968 and 1972 Presidential Elections.” American Political Science Review 71:111-30.

Alemán, Eduardo, and Patricio Navia. 2009. "Institutions and the Legislative Success of 'Strong' Presidents: An Analysis of Government Bills in Chile." Lournal of Legislative Studies 15:401-19.

Alemán, Eduardo, and Sebastián M. Saiegh. 2007. "Legislative Preferences, Political Parties, and Coalition Unity in Chile." Comparative Politics 39: 253-72.

Alemán, Eduardo, and George Tsebelis. 2005. "The Origins of Presidential Conditional Agenda-Setting Power in Latin America." Latin American Research Review 40:3-26.

Alemán, Eduardo, and George Tsebelis. 2011. "Political Parties and Government Coalitions in the Americas." Journal of Politics in Latin America 3: 3-28.

Ames, Barry. 2001. The Deadlock of Democracy in Brazil: Interests, Identities, and Institutions in Comparative Politics. Ann Arbor: University of Michigan Press.

Amorim Neto, Octavio. 2002. "Presidential Cabinets, Electoral Cycles, and Coalition Discipline in Brazil." In Scott Morgenstern and Benito Nacif, eds., Legislative Politics in Latin America. New York: Cambridge University Press, 48-78.

Amorim Neto, Octavio. 2006. "The Presidential Calculus Executive Policy Making and Cabinet Formation in the Americas." Comparative Political Studies 39:415-40.

Amorim Neto, Octavio, and David Samuels. 2011. "Democratic Regimes and Cabinet Politics: A Global Perspective." Revista Ibero-Americana de Estudos Legislativos 1:10-23.

Bagehot, Walter. (1867) 1964. The English Constitution. London: Chapman \& Hall.

Beck, Thorsten, George Clarke, Alberto Groff, Philip Keefer, and Patrick Walsh. 2001. "New Tools in Comparative Political Economy: The Database of Political Institutions." World Bank Economic Review 15:16576.

Brier, Alan, and Bruno Hopp. 2011. "Computer Assisted Text Analysis in the Social Sciences." Quality and Quantity 45:103-28.

Budge, Ian. 2001. Mapping Policy Preferences: Estimates for Parties, Electors, and Governments, 1945-1998, vol. 1. Oxford: Oxford University Press.
Calvo, Ernesto. 2007. “The Responsive Legislature: Public Opinion and Law Making in a Highly Disciplined Legislature." British Journal of Political Science 37:263-80.

Cameron, A. Colin, and Pravin K. Trivedi. 2013. Regression Analysis of Count Data, vol. 53. Cambridge: Cambridge University Press.

Campello, Daniela. 2014. "The Politics of Financial Booms and Crises: Evidence from Latin America." Comparative Political Studies 47:26086.

Carey, John M. 2008. Legislative Voting and Accountability. Cambridge: Cambridge University Press.

Carey, John M., and Matthew Soberg Shugart. 1998. Executive Decree Authority. Cambridge: Cambridge University Press.

Carlin, Ryan E., Gregory J. Love, and Cecilia Martínez-Gallardo. 2014. "Cushioning the Fall: Scandals, Economic Conditions, and Executive Approval.” Political Behavior 37:109-30.

Chasquetti, Daniel. 2001. Democracia, multipartidismo y coaliciones en América Latina: Evaluando la dificil combinación. [Democracy, the multiparty system, and coalitions in Latin America: Evaluating the difficult combination.] Buenos Aires: CLACSO.

Cheibub, José Antonio. 2007. Presidentialism, Parliamentarism, and Democracy. Cambridge: Cambridge University Press.

Cheibub, José Antonio, Adam Przeworski, and Sebastian M. Saiegh. 2004. "Government Coalitions and Legislative Success under Presidentialism and Parliamentarism." British Journal of Political Science 34:56587.

Colomer, Josep M., and Gabriel L. Negretto. 2005. "Can Presidentialism Work Like Parliamentarism?" Government and Opposition 40:60-89.

Coppedge, Michael. 1997. A Classification of Latin American Political Parties. Working paper no. 244, Kellogg Institute for International Studies, University of Notre Dame.

Cox, Gary W. 1990. "Centripetal and Centrifugal Incentives in Electoral Systems.” American Journal of Political Science 34:903-35.

Cox, Gary W., and Scott Morgenstern. 2001. "Latin America's Reactive Assemblies and Proactive Presidents.” Comparative Politics 33:171-89.

Däubler, Thomas, and Kenneth Benoit. 2013. "The Empirical Determinants of Manifesto Content." Presented at the 2013 European Political Science Association annual general conference, Barcelona, paper 205.

Diermeier, Daniel. 2006. "Coalition Government." In Barry R. Weingast and Donald A. Wittman, eds., Oxford Handbook of Political Economy. Oxford: Oxford University Press, 162-79.

Dow, Jay K. 2001. "A Comparative Spatial Analysis of Majoritarian and Proportional Elections.” Electoral Studies 20:109-25.

Doyle, David. 2011. "The Legitimacy of Political Institutions Explaining Contemporary Populism in Latin America." Comparative Political Studies 44:1447-73.

Doyle, David, and Robert Elgie. 2016. "Maximizing the Reliability of Crossnational Measures of Presidential Power." British Journal of Political Science 46 (4): 731-41.

Figueiredo, Argelina Cheibub, and Fernando Limongi. 2000. "Presidential Power, Legislative Organization, and Party Behavior in Brazil.” Comparative Politics 32:151-70.

Figueiredo, Argelina Cheibub, Denise Lopes Salles, and Marcelo Martins Vieira. 2011. "Political and Institutional Determinants of the Executive's Legislative Success in Latin America." Brazilian Political Science Review 3:155-71.

Grimmer, Justin, and Brandon M. Stewart. 2013. "Text as Data: The Promise and Pitfalls of Automatic Content Analysis Methods for Political Texts." Political Analysis 21:267-97.

Hagopian, Frances, and Scott P. Mainwaring. 2005. The Third Wave of Democratization in Latin America: Advances and Setbacks. Cambridge: Cambridge University Press. 
Hakhverdian, Armen. 2009. "Capturing Government Policy on the LeftRight Scale: Evidence from the United Kingdom, 1956-2006.” Political Studies 57:720-45.

Johnson, Gregg B., and Brian F. Crisp. 2003. "Mandates, Powers, and Policies." American Journal of Political Science 47:128-42.

Kaplan, Stephen B. 2013. Globalization and Austerity Politics in Latin America. Cambridge: Cambridge University Press.

Kaufman, Robert R., and Alex Segura-Ubiergo. 2001. "Globalization, Domestic Politics, and Social Spending in Latin America: A Time-Series Cross-Section Analysis, 1973-97." World Politics 53:553-87.

Kiewit, Rodrik, and Matthew McCubbins. 1991. The Logic of Delegation. Chicago: University of Chicago Press.

Klemmensen, Robert, Sara Binzer Hobolt, and Martin Ejnar Hansen. 2007. "Estimating Policy Positions Using Political Texts: An Evaluation of the Wordscores Approach." Electoral Studies 26:746-55.

Laver, Michael, Kenneth Benoit, and John Garry. 2003. "Extracting Policy Positions from Political Texts Using Words as Data." American Political Science Review 97:311-31.

Laver, Michael, and John Garry. 2000. "Estimating Policy Positions from Political Texts." American Journal of Political Science 44:619-34.

Laver, Michael, and Ernest Sergenti. 2011. Party Competition: An AgentBased Model. Princeton, NJ: Princeton University Press.

Linz, Juan J. 1990. “The Perils of Presidentialism.” Lournal of Democracy 1:51-69.

Lo, James, Sven-Oliver Proksch, and Jonathan B. Slapin. 2014. "Ideological Clarity in Multiparty Competition: A New Measure and Test Using Election Manifestos." British Journal of Political Science 46:1-20.

Luna, Juan P., and Elizabeth J. Zechmeister. 2005. "Political Representation in Latin America: A Study of Elite-Mass Congruence in Nine Countries." Comparative Political Studies 38:388-416.

Maeda, Ko. 2010. "Two Modes of Democratic Breakdown: A Competing Risks Analysis of Democratic Durability." Lournal of Politics 72:1129-43.

Mainwaring, Scott. 1993. "Presidentialism, Multipartism, and Democracy: The Difficult Combination." Comparative Political Studies 26:198-28.

Mainwaring, Scott, and Matthew Soberg Shugart. 1997. Presidentialism and Democracy in Latin America. Cambridge: Cambridge University Press.

Martínez-Gallardo, Cecilia. 2011. "Designing Cabinets: Presidential Politics and Cabinet Instability in Latin America." Working paper no. 375, Kellogg Institute for International Studies, University of Notre Dame.

Mejía Acosta, Andrés. 2009. Informal Coalitions and Policymaking in Latin America. New York: Routledge.

Micozzi, Juan Pablo, and Hirokazu Kikuchi. 2015. "Scaling the Progressive Ladder: Partisanship, Ambition, and Roll-Call Behavior in the Argentine House and Senate." Unpublished paper, Instituto Tecnológico Autónomo de México.

Montero, Mercedes Garca. 2009. Presidentes y parlamentos: ¿quién controla la actividad legislativa en América Latina? [Presidents and parliaments: Who controls the legislative activity in Latin America?] Madrid: CIS.

Murillo, Carla Victoria Jara. 2007. "Discurso presidencial costarricense: estructura formal y tópica del último mensaje ante los diputados (19022002)." [Costa Rican presidential discourse: The formal and topical structure of the final state of the union address to members of congress.] Revista de filologa y lingüstica de la Universidad de Costa Rica 32:14183.

Negretto, Gabriel L. 2004. "Government Capacities and Policy Making by Decree in Latin America: The Cases of Brazil and Argentina." Comparative Political Studies 37:531-62.

Negretto, Gabriel L. 2006. "Minority Presidents and Democratic Performance in Latin America." Latin American Politics and Society 48:63-92.
PELA. 2005. Proyecto de Elites Latinoamericanas, 1994-2005, Universidad de Salamanca.

Pérez-Liñán, Anbal. 2007. Presidential Impeachment and the New Political Instability in Latin America. Cambridge: Cambridge University Press.

Poole, Keith T., and Howard Rosenthal. 1997. Congress: A PoliticalEconomic History of Roll Call Voting. New York: Oxford University Press.

Pop-Eleches, Grigore. 2008. From Economic Crisis to Reform: IMF Programs in Latin America and Eastern Europe. Princeton, NJ: Princeton University Press.

Power, Timothy, and Cesar Zucco. 2014. "Introducing the Brazilian Legislative Survey Wave 7." Presented at the workshop "The Brazilian Political Elite: Ideology, Values and Policy Preferences," University of Oxford.

Power, Timothy J., and Cesar Zucco Jr. 2009. "Estimating Ideology of Brazilian Legislative Parties, 1990-2005: A Research Communication." Latin American Research Review 44:218-46.

Pribble, Jennifer. 2013. Welfare and Party Politics in Latin America. Cambridge: Cambridge University Press.

Proksch, Sven-Oliver, and Jonathan B. Slapin. 2009. "How to Avoid Pitfalls in Statistical Analysis of Political Texts: The Case of Germany." German Politics 18:323-44.

Raile, Eric D., Carlos Pereira, and Timothy J. Power. 2010. "The Executive Toolbox: Building Legislative Support in a Multiparty Presidential Regime." Political Research Quarterly 64:323-34.

Sagarzazu, Inaki. 2011. "Weak Party Institutionalization and the Dynamics of Political Dialogue." Presented at the 2011 annual meeting of the American Political Science Association, Seattle, WA.

Saiegh, Sebastian M. 2009a. "Political Prowess or 'Lady Luck'? Evaluating Chief Executives' Legislative Success Rates." Iournal of Politics 71:134256.

Saiegh, Sebastian M. 2009b. "Recovering a Basic Space from Elite Surveys: Evidence from Latin America." Legislative Studies Quarterly 34:117-45.

Saiegh, Sebastian M. 2011. Ruling by Statute: How Uncertainty and Vote Buying Shape Lawmaking. Cambridge: Cambridge University Press.

Samuels, David. 2003. Ambition, Federalism, and Legislative Politics in Brazil. Cambridge: Cambridge University Press.

Samuels, David. 2008. "Brazilian Democracy under Lula and the PT." Constructing Democratic Governance in Latin America. Baltimore: Johns Hopkins University Press.

Samuels, David J., and Matthew S. Shugart. 2010. Presidents, Parties, and Prime Ministers: How the Separation of Powers Affects Party Organization and Behavior. Cambridge: Cambridge University Press.

Shugart, Matthew Soberg, and John M. Carey. 1992. Presidents and Assemblies: Constitutional Design and Electoral Dynamics. Cambridge: Cambridge University Press.

Slapin, Jonathan B., and Sven-Oliver Proksch. 2008. "A Scaling Model for Estimating Time-Series Party Positions from Texts." American Journal of Political Science 52:705-22.

Stepan, Alfred, and Cindy Skach. 1993. "Constitutional Frameworks and Democratic Consolidation: Parliamentarianism versus Presidentialism." World Politics 46:1-22.

Stokes, Susan. 2001. Mandates and Democracy: Neoliberalism by Surprise in Latin America. Cambridge: Cambridge University Press.

Strøm, Kaare. 1990. "A Behavioral Theory of Competitive Political Parties." American Journal of Political Science 34:565-98.

Strøm, Kaare, Wolfgang C. Müller, and Torbjörn Bergman, eds. 2003. Delegation and Accountability in Parliamentary Democracies. Oxford: Oxford University Press.

Wiesehomeier, Nina, and Kenneth Benoit. 2009. "Presidents, Parties, and Policy Competition." Lournal of Politics 71:1435-47. 